\title{
Hambatan Guru Olahraga Menulis Karya Tulis Ilmiah Di Lingkungan JSIT Wilayah Bengkulu
}

\author{
Juwita $^{1}$, Dian Ramadan Lazuardi ${ }^{2}$, Diah Selviani ${ }^{3}$ \\ Universitas Dehasen Bengkulu ${ }^{1,3}$, STKIP Lubuk Linggau ${ }^{2}$ \\ juwitarhazes@gmail.com, dianramadan78@gmail.com, \\ diah.selviani@unived.ac.id
}

\begin{abstract}
Received: 19 Januari 2021; Revised: 26 Februari 2021; Accepted: 28 April 2021
DOI: http://dx.doi.org/10.37905/aksara.7.2.273-282.2021
\end{abstract}

\begin{abstract}
ABSTRAK
Penelitian ini bertujuan untuk mengetahui hambatan guru olahraga menulis karya tulis ilmiah di lingkungan JSIT Bengkulu. 76\% responden mempunyai hambatan menyuusn KTI, 96\% responden mempunyai hambatan kurangnya motivasi. 68\% responden mempunyai cara menghadapi permasalahan tersebut dengan mengingat pentingnya menyusun KTI. 56\% responden mempunyai hambatan luar diri dengan tidak ada pendamping pada menulis KTI. 76\% responden mempunyai cara mengatasi dengan mencari informasi dari internet. $96 \%$ responden menyadari hambatan dari dalam dan luar diri. 96\% responden mengetahui dampak pada peningkatan penyusunan KTI. $80 \%$ responden menyadari hal yang belum dilakukan dalam menghadapi hambatan menulis KTI. $60 \%$ responden mengikuti latihan penyusunan KTI sudah efektif.
\end{abstract}

Kata kunci: Hambatan Guru Olahraga Menulis KTI

\begin{abstract}
This study aims to determine the obstacles for sports teachers to write scientific papers in the JSIT Bengkulu environment. $76 \%$ of respondents have barriers to preparing KTI, 96\% of respondents have barriers of lack of motivation. $68 \%$ of respondents have a way of dealing with these problems by remembering the importance of compiling KTI. 56\% of respondents have external barriers with no companion on writing KTI. $76 \%$ of respondents have a way to solve it by looking for information from the internet. $96 \%$ of respondents are aware of internal and external obstacles. $96 \%$ of respondents know the impact on increasing the preparation of KTI. $80 \%$ of respondents are aware of what has not been done in the face of obstacles in writing KTI. $60 \%$ of respondents who participated in the training on the preparation of KTI were effective.

Keywords: Barriers to Writing Sports Teachers in KTI
\end{abstract}

\section{PENDAHULUAN}

Secara yuridis Undang-Undang Nomor 20 tahun 2003 tentang Sistem Pendidikan Nasional pasal 39 ayat 3 menyebutkan bahwa, pendidik yang mengajar pada satuan pendidikan dasar dan menegah disebut guru dan pendidik yang 
mengajar pada satuan pendidikan tinggi disebut dosen. Dengan demikian profesi pendidik

terbagi menjadi dua yakni guru dan dosen.Menulis sebuah karya ilmiah bukanlah hal yang tabuh lagi bagi dosen, pendidik, dan mahasiswa, kegiatan ini sudah menjadi sebuah kebutuhan bagi para pendidik khususnya dosen dan guru. Dengan demikian, karya tulis ilmiah sejatinya adalah hal yang tidak asing lagi bagi dosen, guru serta mahasiswa, karena sudah dimulai dari pembuatan makalah, laporan penelitian, skripsi, tesis hingga sampai disertasi. Namun demikian, hal ini ini tidak serta - merta menjadikan para dosen, guru dan mahasiswa dengan mudah dapat menghasilkan karya tulis ilmiah.

Karya Tulis Ilmiah merupakan kekayaan intelektual bagi suatu lembaga dan negara secara individunya merupakan media aktualisasi diri pada seorang peneliti, dan arti kata lain karya tulis ilmiah adalah suatu kemampuan dan pemahaman pada bacaan, dengan kemmapuan berfikir kritis dalam mengembangkan ilmu pengetahuan selaras pada pendapat dari teori Kurniadi 2017, Ndjoeroemana, Y 2012 dan K Masiani 2020.

Hal ini disebabkan banyak hal yang menjadi hambatan dalam menulis, baik kendala internal dan kendala eksternal. Menulis belum menjadi budaya yang melekat dalam kehidupan masyarakat, terutamanya menulis dalam bentuk karya tulis ilmiah. Indikatornya sudah jelas, publikasi internasional dari masyarakat kita sendiri masih rendah dan banyak ditemukan akademisi yang kariernya terhambat karena minimnya publikasi dan penelitian.

Menulis adalah suatu kegiatan yang menuangkan pikiran, gagasan dan perasaan seseorang dan arti kata lain menulis adalah melukiskan lambang lambang grafis yang menghasilkan suatu bahasa yang dapat dipahami oleh seseorang serta menulis merupakan hasil dari pikiran dan perasaan yang dapat dituangkan pada aktivitas gerakan motorik. Hal ini sesuai dengan teori dari Tarigan 2013, Vera Sardila 2015, Simarmata 2019 dan Sidiq \& Bisri M 2016.

Menulis Karya Tulis Ilmiah, selalu ada hambatan yang ditemukan oleh pemula atau yang sedang menulis, dalam teori berikut beberapa hambatan tersebut adalah terdapat hambatan non kebahasaan seperti hambatan eksternal - lingual yang di alami oleh pengguna bahasa selain itu hamabatanya terdapat faktor tidak lengkapnya panduan dan bahan serta faktor teknis bimbingan dalam proses menulis, hambatan berikutnya ditemukan bahwa penulis tidak mempunyai bakat dalam menulis diketahui dengan tidak memahami langkah menulis dengan baik, tidak siap menerima keritikan orang lain, tidak memilki waktu, dan tidak bisa melanjutkan langkah selanjutnya. Hal ini sesuai dengan teori Yulianingsih \& Sultan 2020, Syaefullah, drg, M.Pd 2015, Darmono \& M. Hasan 2002, Nugroho,H 2011.

\section{Metode Penelitian}

Sebelum melakukan penelitian harus diketahui terlebih dahulu mengenai pendekatan dan jenis penelitian yang dipergunakan, hal ini bertujuan untuk mempermudah pemecahannya. Ditinjau dari jenis masalah yang diselidiki dan teknik yang digunakan, maka penelitian ini menggunakan jenis penelitian kualitatif dengan desain penelitian deskriptif. Jenis penelitian deskriptif 
kualitatif menggambarkan kondisi apa adanya, tanpa memberi perlakuan atau manipulasi pada variable yang diteliti.

Penelitian deskriptif merupakan penelitian untuk mencari fakta dengan interpretasi yang tepat dengan mempelajari permasalahan dan penelitian ini juga bertujuan untuk mengumpulkan informasi mengenai permasalahan tersebut serta melakukan eksplorasi dan klarifikasi secara sistematika dengan mendeskripsikan suatu gejala, peristiwa yang terjadi pada saat sekarang. Hal ini selaras dengan teori Zellatifany\&Mudiyanto, Suhardi 2012, Prihartono 2016, Sujana\&Ibrahim 1989, Darwis S.Kp\&Danim 2003, Gulo W 2002.

Deskriptif persentase ini di olah dengan dengan cara frekuensi dibagi jumlah responden dikali 100 persen, seperti dikemukakan Sudjana (2001:129) adalah sebagai berikut :

$$
\begin{aligned}
& \mathrm{P}=\frac{F}{N !} x 100 \% \\
& \text { Keterangan : } \\
& \mathrm{P}: \text { Persentase } \\
& \mathrm{F}: \text { Frekuensi } \\
& \mathrm{N}: \text { Jumlah responden } \\
& 100 \% \quad: \text { Bilangan tetap }
\end{aligned}
$$

Tujuan penelitian ini adalah untuk mengetahui hambatan guru olahraga menulis karya tulis ilmiah di lingkungan JSIT wilayah Bengkulu hambatan yang dialami guru dalam menulis karya ilmiah, analisis data ini dengan penyebaran angket kepada guru olahraga JSIT wilayah Bengkulu. Tempat yang dipilih dalam penelitian ini adalah SMAIT IQRA . Waktu pelaksanaan penelitian antara bulan Maret sampai dengan Mei tahun 2021. Teknik pengumpulan data yang digunakan adalah kuisioner dan dokumentasi. Keabsahan data menggunakan teknik triangulasi sumber.

Analisis data penelitian ini adalah analisis dekriptif kualitatif yang dilakukan dalam empat tahapan yang saling terkait: pengumpulan data, reduksi data, menampilkan data, kemudian verifikasi dan penarikan kesimpulan.

\section{Hasil dan Pembahasan \\ Hasil}

Hasil penelitian pada judul penelitian hambatan guru olahraga menulis karya tulis ilmiah di lingkungan JSIT wilayah Bengkulu diketahui bahwa, terdapat jawaban responden guru olahraga yang mempunyai jawaban yang hampir sama dengan jawaban responden lainya artinya, responden mempunyai permasalahan yang sama terlihat pada hasil analisis butir soal - soal di bawah : 


\begin{tabular}{|c|c|c|c|c|}
\hline Soal Butir 1 & $\begin{array}{c}\text { Jumlah } \\
\text { Jawaban }\end{array}$ & Rumus & Keterangan & $\begin{array}{c}\text { Keterangan } \\
\text { Dalam Bentuk Diagram }\end{array}$ \\
\hline $\begin{array}{l}\text { Apakah Bapak/Ibu } \\
\text { sudah mempunyai } \\
\text { Karya Tulis Ilmiah? } \\
\text { a. Sudah } \\
\text { b. belum }\end{array}$ & $\begin{array}{l}\text { jawaban A } \\
=1 \\
\text { jawaban B } \\
=24\end{array}$ & $\begin{array}{l}\text { Rumus : } \\
\frac{A}{A+B} \times 100 \% \\
\mathrm{~A}=\frac{1}{25} \times 100 \\
\%=4 \\
\mathrm{~B}=\frac{24}{25} \times 100 \\
\%=96\end{array}$ & $\begin{array}{l}\text { Berdasarkan } \\
\text { keseluruhandata } \\
\text { responden pada butir } \\
\text { soal 1 menunjukan } \\
\text { jumlah jawaban yang } \\
\text { memilih A adalah satu } \\
\text { yaitu 4\% dan yang } \\
\text { memilih jawaban B } \\
\text { dengan jumlah 96 \% } \\
\text { artinya bahwa sebagian } \\
\text { besar responden belum } \\
\text { mempunyai Karya } \\
\text { Tulis Ilmiah. }\end{array}$ & Butir soal \\
\hline Soal Butir 2 & $\begin{array}{c}\text { Jumlah } \\
\text { Jawaban }\end{array}$ & Rumus & Keterangan & \\
\hline $\begin{array}{l}\text { ApakahBapak/Ibu } \\
\text { memilikihambatan } \\
\text { dalampenyusunan } \\
\text { Karya Tulis Ilmiah ? } \\
\text { a. Tidak Memiliki } \\
\text { b. Memiliki }\end{array}$ & $\begin{array}{l}\text { jawaban } \mathrm{A} \\
=6 \\
\text { jawaban } \mathrm{B} \\
=19\end{array}$ & $\begin{array}{l}\text { Rumus : } \\
\frac{A}{A+B} \times 100 \% \\
\mathrm{~A}=\frac{6}{25} \times 100 \\
\%=24 \\
\mathrm{~B}=\frac{19}{25} \times 100 \\
\%=76\end{array}$ & $\begin{array}{l}\text { Berdasarkan persentase } \\
\text { jawaban butir soal no } 2 \\
\text { di dapatkan jawaban A } \\
\text { sebanyak } 24 \% \text { dan } \\
\text { jawaban B sebanyak } 76 \\
\% \text { dengan ini artinya } \\
\text { bahwa sebagian besar } \\
\text { responden mempunyai } \\
\text { hambatan dalam } \\
\text { penyusunan Karya } \\
\text { Tulis Ilmiah. }\end{array}$ & Butir Soal 2 \\
\hline Soal Butir 3 & $\begin{array}{c}\text { Jumlah } \\
\text { Jawaban }\end{array}$ & Rumus & Keterangan & \\
\hline $\begin{array}{l}\text { Apa hambatan } \\
\text { terbesar dari dalam } \\
\text { diri } \quad \text { Bapak/Ibu } \\
\text { hadapi } \quad \text { dalam } \\
\text { penyusunan Karya } \\
\text { Tulis Ilmiah } \\
\text { a. Kurang } \\
\quad \text { Motivasi } \\
\text { b. Malas }\end{array}$ & $\begin{array}{l}\text { Jumlah } \\
\text { jawaban A } \\
=24 \\
\text { Jumlah } \\
\text { jawaban B } \\
=1\end{array}$ & $\begin{array}{l}\text { Rumus : } \\
\frac{A}{A+B} \times 100 \% \\
\mathrm{~A}=\frac{24}{25} \times 100 \\
\%=96 \\
\mathrm{~B}=\frac{1}{25} \times 100 \\
\%=4\end{array}$ & $\begin{array}{l}\text { Berdasarkan persentase } \\
\text { jawaban butir soal } 3 \text { di } \\
\text { dapatkan jawaban A } \\
\text { sebanyak } 96 \% \text { dan } \\
\text { jawaban B sebanyak } \\
4 \% \text { artinya bahwa } \\
\text { sabagian besar } \\
\text { responden mempunyai } \\
\text { hambatan dalam diri } \\
\text { yaitu kurang motivasi }\end{array}$ & Butir Soal 3 \\
\hline
\end{tabular}




\begin{tabular}{|c|c|c|c|c|}
\hline Soal Butir 4 & $\begin{array}{c}\text { Jumlah } \\
\text { Jawaban }\end{array}$ & Rumus & Keterangan & \\
\hline $\begin{array}{l}\text { Bagaimana cara } \\
\text { Bapak/Ibu } \\
\text { menghadapi } \\
\text { hambatan dari dalam } \\
\text { diri Bapak/Ibu dalam } \\
\text { menulis Karya Tulis } \\
\text { Ilmiah ? } \\
\text { A Mengingat kembali } \\
\text { tujuan awal } \\
\text { penyusunan KTI } \\
\text { p. Melakukan aktifitas } \\
\text { bila di luar } \\
\text { penyusunan KTI }\end{array}$ & $\begin{array}{l}\text { jawaban A } \\
=17 \\
\text { jawaban B } \\
=8\end{array}$ & $\begin{array}{l}\text { Rumus : } \\
\frac{A}{A+B} \times 100 \% \\
\mathrm{~A}=\frac{17}{25} \times 100 \\
\%=68 \\
\mathrm{~B}=\frac{8}{25} \times 100 \\
\%=32\end{array}$ & $\begin{array}{l}\text { Berdasarkan persentase } \\
\text { jawaban butir soal } 4 \text { di } \\
\text { dapatkan jawaban A } \\
\text { sebanyak } 60 \% \text { dan } \\
\text { jawaban B sebanyak } \\
32 \% \text { artinya bahwa } \\
\text { sabagian } \text { besar } \\
\text { responden menghadapi } \\
\text { hambatan dari dalam } \\
\text { diri pada menulis } \\
\text { Karya Tulis Ilmiah } \\
\text { dengan melakukan } \\
\text { aktifitas bila di luar } \\
\text { penyusunan Karya } \\
\text { Tulis Ilmiah. }\end{array}$ & Butir Soal 4 \\
\hline Soal Butir 5 & $\begin{array}{c}\text { Jumlah } \\
\text { Jawaban }\end{array}$ & Rumus & Keterangan & \\
\hline \begin{tabular}{|l} 
Apa hambatan \\
terbesar luar diri \\
Bapak/Ibu hadapi \\
dalam menulis \\
Karya Tulis Ilmiah ? \\
a.Tidak ada \\
pendamping dalam \\
penyusunan KTI \\
p. Minimnya \\
pengetahuan \\
dalam menyusun \\
KTI
\end{tabular} & $\begin{array}{l}\text { jawaban A } \\
=14 \\
\text { jawaban } \mathrm{B} \\
=11\end{array}$ & $\begin{array}{l}\text { Rumus : } \\
\frac{A}{A+B} \times 100 \% \\
\mathrm{~A}=\frac{14}{25} \times 100 \\
\%=56 \\
\mathrm{~B}=\frac{11}{25} \times 100 \\
\%=44\end{array}$ & $\begin{array}{l}\text { Berdasarkan persentase } \\
\text { jawaban butir soal } 5 \text { di } \\
\text { temukan jawaban A } \\
\text { sebanyak } 14 \% \text { dan } \\
\text { jawaban B sebanyak } \\
11 \% \text { artinya bahwa } \\
\text { sabagian besar } \\
\text { responden mempunyai } \\
\text { hambatan dari luar diri } \\
\text { dalam menulis Karya } \\
\text { Tulis Ilmiah yaitu } \\
\text { minimnya pengetahuan } \\
\text { dalam menyusun } \\
\text { Karya Tulis Ilmiah }\end{array}$ & Butir Soal 5 \\
\hline Soal Butir 6 & $\begin{array}{c}\text { Jumlah } \\
\text { Jawaban }\end{array}$ & Rumus & Keterangan & \\
\hline
\end{tabular}




\begin{tabular}{|c|c|c|c|c|}
\hline 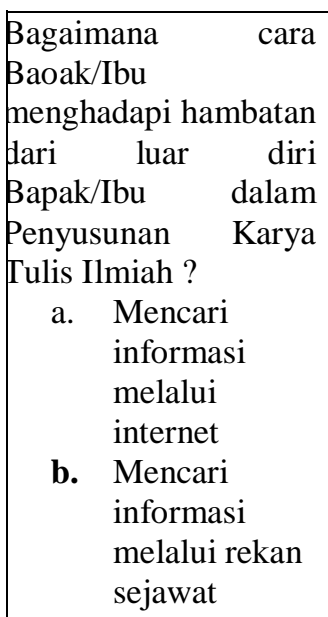 & $\begin{array}{l}\text { jawaban A } \\
=19 \\
\text { jawaban B } \\
=6\end{array}$ & $\begin{array}{l}\text { Rumus : } \\
\frac{A}{A+B} \times 100 \% \\
\mathrm{~A}=\frac{19}{25} \times 100 \\
\%=76 \\
\mathrm{~B}=\frac{6}{25} \times 100 \\
\%=24\end{array}$ & $\begin{array}{l}\text { Berdasarkan persentase } \\
\text { jawaban butir soal } 6 \text { di } \\
\text { temukan jawaban A } \\
\text { sebanyak } 76 \% \text { dan } \\
\text { jawaban B sebanyak } \\
24 \% \text { ini artinya bahwa } \\
\text { sabagian besar } \\
\text { responden mempunyai } \\
\text { cara menghadapi } \\
\text { hambatan dari luar } \\
\text { dirinya dengan mencari } \\
\text { informasi melalui } \\
\text { teman sejawat. }\end{array}$ & Butir Soal 6 \\
\hline Soal Butir 7 & $\begin{array}{c}\text { Jumlah } \\
\text { Jawaban }\end{array}$ & Rumus & Keterangan & \\
\hline $\begin{array}{l}\text { Apakah cara yang } \\
\text { Bapak/Ibu lakukan } \\
\text { dalam menghadapi } \\
\text { hambatan dari dalam } \\
\text { dan luar diri dalam } \\
\text { penyusunan KTI } \\
\text { sudah fektif? } \\
\text { a. Sudah efektif } \\
\text { b. Belum efektif }\end{array}$ & $\begin{array}{l}\text { jawaban A } \\
=1 \\
\text { jawaban } \mathrm{B} \\
=24\end{array}$ & $\begin{array}{l}\text { Rumus : } \\
\frac{A}{A+B} \times 100 \% \\
\mathrm{~A}=\frac{1}{25} \times 100 \\
\%=4 \\
\mathrm{~B}=\frac{24}{25} \times 100 \\
\%=96\end{array}$ & $\begin{array}{l}\text { Berdasarkan persentase } \\
\text { jawaban butir soal } 7 \text { di } \\
\text { temukan jawaban A } \\
\text { sebanyak } 4 \% \text { dan } \\
\text { jawaban B sebanyak } \\
96 \% \text { ini artinya bahwa } \\
\text { sabagian besar } \\
\text { responden sudah } \\
\text { efektif dalam } \\
\text { menghadapi hambatan } \\
\text { dari dalam dan luar diri } \\
\text { responden terhadap } \\
\text { penulisan Karya Tulis } \\
\text { Ilmiah. }\end{array}$ & Butir Soal 7 \\
\hline Soal Butir 8 & $\begin{array}{c}\text { Jumlah } \\
\text { Jawaban }\end{array}$ & Rumus & Keterangan & \\
\hline
\end{tabular}




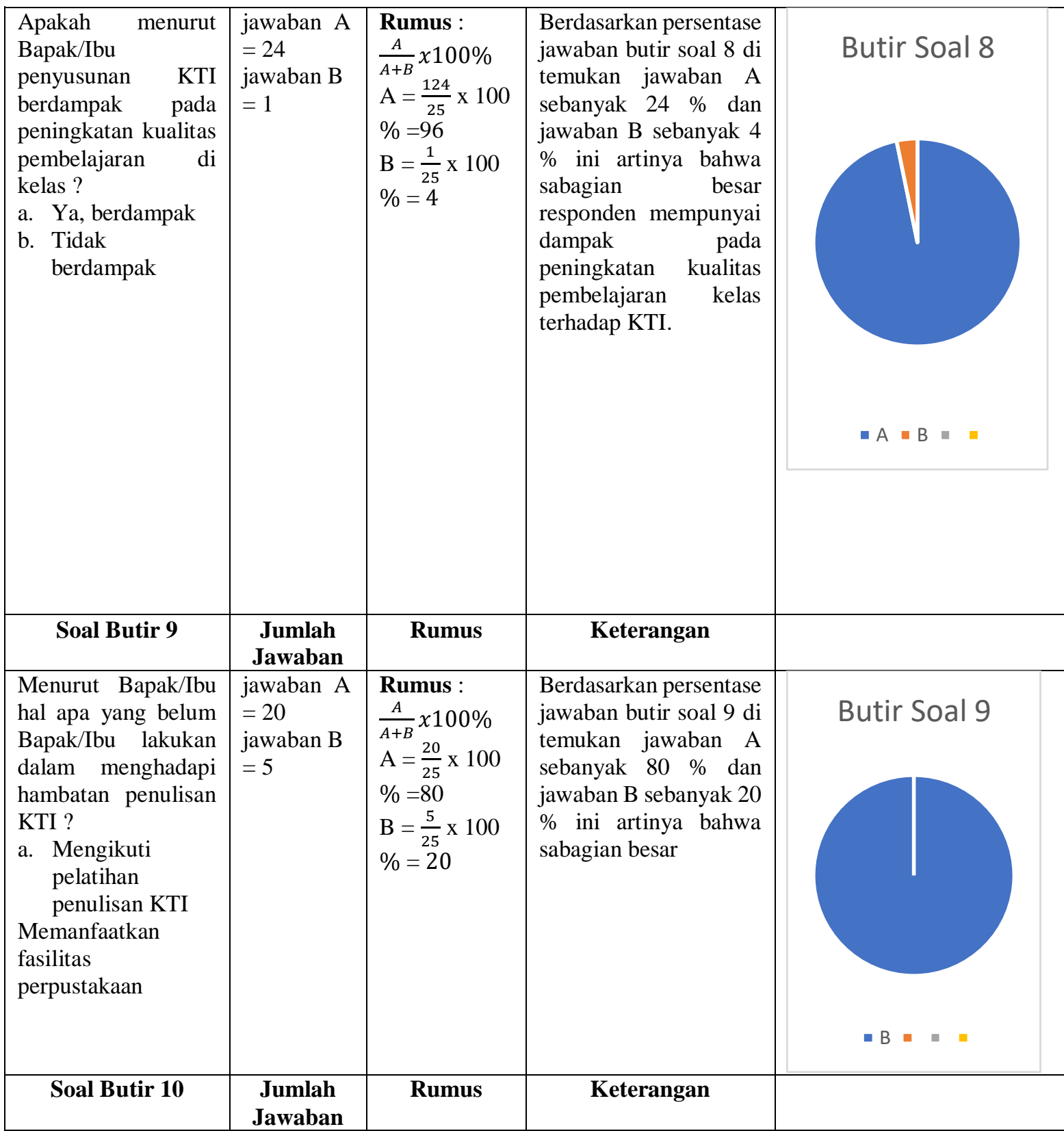




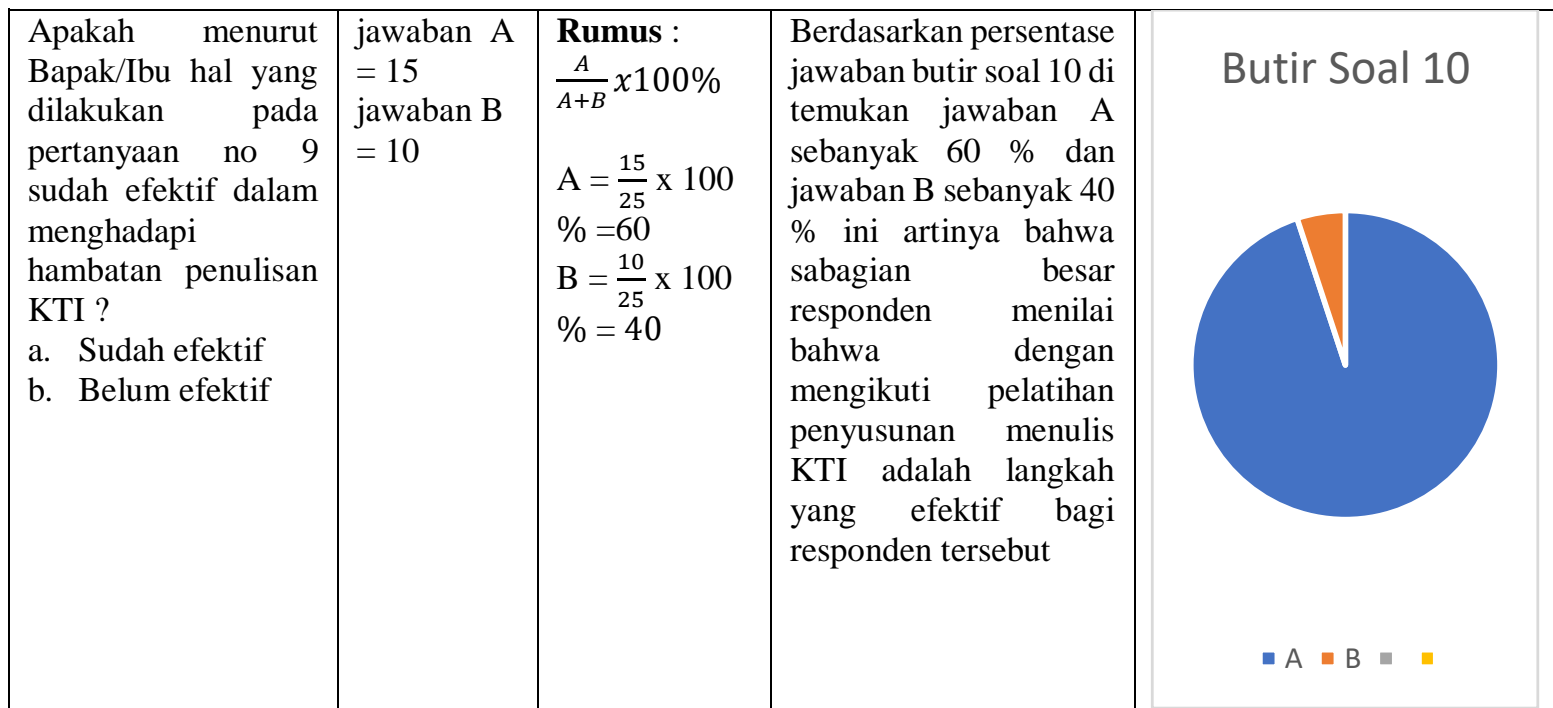

\section{Pembahasan}

Karya ilmiah biasanya disusun dalam mencari jawaban atas suatu permasalahan mengenai suatu hal dan pembuktian kebenaran dalam objek tulisan. Hasil penelitian saat peneliti menanyakan mengenai keruntutan dan keterkaitan antar bagian dalam penulisan karya ilmiah, seperti yang diungkapkan salah satu responden atas nama Rahmadi. Beliau mengungkapkan bahwa merasa kesulitan dalam mengaitkan antar bagian dalam isi kajian tersebut dan menemukan hambatan untuk mendapatkan literasi ilmu yang berkaitan dengan isi karyanya tersebut, sehingga aktifitas menulis tertunda dengan waktu cukup lama. Sesuai dengan yang diungkapkan Kunandar (2013:27), bahwa ciri karya ilmiah adalah mengikuti metode keilmuan, runtut, sistematis, dan akurat atau teliti, objektif, lugas, dan dapat dipercaya, dapat dikaji atau diteliti ulang dan dibuktikan, terbuka untuk umum.

\section{PENUTUP}

Berdasarkan dari data responden yang telah di analisis di ketahui bahwa sebagian besar responden mempunyai hambatan terbesar dari diri sendiri maupun dari luar diri sendiri. Hambatan terbesar dari dalam dirinya responden yaitu kurangnya motivasi, timbulnya rasa malas, hilangnya rasa mood serta kurang percaya diri. Dan hambatan terbesar dari luar dirinya responden adalah kurangnya informasi literatur,kurangnya dukungan lingkungan setempat, fasilitas kurang mendukung atau tidak memadai sehingga menjadikan responden sebagai faktor penghambat bagi responden dalam langkah penulis pemula. Setelah dilakukan analisis perbutir soal. Dapat disimpulkan bahwa responden perlu diberikan pelatihan penulisan Karya Tulis Ilmiah sebagai penunjang wawasan informasi responden, sehingga dengan adanya pelatihan tersebut diharapkan akan mempermudah membantu responden dalam menulis Karya Tulis Ilmaih dengan sistematika yang benar dan baik nantinya. 


\section{DAFTAR PUSTAKA}

Darmono,\&M.Hasan,A.(2002).MenyelesaikanSkripsiDalamSatuSemester.InDarm ono, \&A.M.Hasan,MenyelesaikanSkripsiDalamSatuSemester(pp.120).Jakarta:PT Grasindo.

Darwis,S.Kp,\&Danim,P.(2003).MetodePenelitianKebidananProsedurKebijakanD anEtik.

InDarwis,S.Kp,\&P.Danim,MetodePenelitianKebidananProsedurKebijakan Dan Etik(pp.1-72).Jakarta:BukuKedokteranEGC.

Gulo,W.(2002).MetedeologiPenelitian.InW.Gulo,MetedeologiPenelitian(pp.1262). Jakarta:GramediaWidiasaranaIndonesia.

Kurniadi,F.(2017).Penulisan KaryaTulis Ilmiah Mahasiswa Dengan Media Aplikasi Pengolahan Data. Jurnal Pendidikan Bahasa Dan Sastra Indonesia,1(2),267-277.K Masiani - Jurnal Pari, 2020 - ejournalbalitbang.kkp.go.id

Kuntarto, Niknik M dan Putranto Hendar.Menulis Karya Ilmiah Yogyakarta : Indopublika Menurut Arikunto (2006;250) metode analisis deskriptif

Ndjoeroemana,Y.(2012).PengembanganModelInkuiriSosialYangDimodifikasiPad a PembelajaranMenulisKaryaIlmiah.JurnalPendidikanBahasaDanSastraIndo nesia, 1(2),137-142.

Nugroho,H.(2011).CaraMudahMenjadiGuruPenulis.InH.Nugroho,CaraMudahMe njadi GuruPenulis(pp.51-59).Semarang:PTDharaPrize

Vera Sardila, 2015. Jurnal Pemikiran Islam,Vol.40,No.2

Syaefullah,drg.M.Pd,P.(2015).PrinsipDasarPenyusunanDanPenulisanKaryaTulisIl miah.

InP.Syaefullah,drg.M.Pd,PrinsipDasarPenyusunanDanPenulisanKaryaTuli s Ilmiah(pp.1-125).Jakarta:PTGrasindo,anggotaikapi.

Sidiq,M.,\&Bisri,M.I.(2016).Dasar-DasarMenulis.InM.Sidiq,\&M.I.Bisri,Dasar-

Dasar MenulisDanPenerapannya(pp.1

154).Malang:TunggalMandiriPublishing

Simarmata,J.(2019).KitaMenulis.InJ.Simarmata,SemuaBisaMenulisBuku(pp.1 146). Jakarta:YayasanKitaMenulis

Suhardi,D.(2012).PeranSMPBerbasisPesantrenSebagaiUpayaPenanamanPendidia n KarakterKepadaGenerasiBangsa.JurnakPendidikanBerkarakter,2(3),3163328.

Sugiyono, 2002:62).(J.Supranto, 2001:80)

Sudjana,\&Ibrahim.(1989).MetodePenelitianDeskriptif.InSujana,\&Ibrahim,Metode PenelitianDeskriptif(p.65).Jakarta:CinthiaMornisSartono.

Tarigan, Hendry Guntur. 2013. Menulis Sebagai Suatu Keterampilan Berbahasa. Bandung: Angkasa.

Taniredja, Tukiran Dkk. 2016. Guru Yang Profesional. Bandung : Alfabeta

Prihartono,A.W.(2016).SuratKabar\&KonvergensiMedia(StudiDeskriptifKualitatif Model

Yulianingsih,D.,\&Sultan.(2020).KlasifikasiKesalahanDanHambatanPenggunaanB ahasa IndonesiaSebagaiAkademik.El-TsaqafahJurnalPBA,19(1),72-85 
Zellatifany,C.M.,\&Mudiyanto,B.(2018).TipePenelitianDeskripsiDalamIlmuKomu nikasi. JurnalDaikom,1(2),83-89. 